\title{
The Modern Novella or nouvelle beyond the Short Story and the Novel
}

\author{
José Cardona-López ${ }^{1}$
}

The modern novella or nouvelle is an object of artistic order of concentration and suggestion. In it, there is a tension between the objective and the subjective, circumstances that bring it closer to other literary forms different from the short story and the novel. Based on this idea, this article presents and discusses the closeness of the modern novella with drama and poem, literary and artistic expressions that also achieve their aesthetic effects through a short or medium length. [Article copies available for a fee from The Transformative Studies Institute. E-mail address: journal@transformativestudies.org Website: http://www.transformativestudies.org (C2021 by The Transformative Studies Institute. All rights reserved.]

KEYWORDS: Novella, Elusiveness, Second times, Drama, Poem.

The novella is a literary form that emerges in the Italian Fourteenth Century, during the early Renaissance. Its "official birth" occurred with Giovanni Boccaccio's The Decameron (1351-1353). Later the modern expression of the novella is born during the beginnings of that modernity located between the end of the 18th and 19th Centuries that Octavio Paz identifies in Los hijos del limo (1974) and calls it "principio de la edad moderna" (20). More precisely, the modern novella started breathing in the arms of German Romanticism.

\footnotetext{
${ }^{1}$ José Cardona-López, Ph.D., is Regents Professor of Hispanic American Literature and Creative Writing at Texas A\&M International University. His research interest is focused on Spanish American narrative (especially on short novel or nouvelle) and poetry. He is a Contributing Editor to the Handbook of Latin American Studies (Library of Congress). His book entitled Teoria y práctica de la nouvelle (2003) is devoted to present and discuss the most important theoretical approaches to the study of modern nouvelle or novella. As fiction writer he has published the short novel Mercedes (e-book, 2014), the novel Sueños para una siesta (1986), and several short stories collections: La puerta del espejo (1983), Siete y tres nueve (2003), Todo es adrede (1991, 2009), and Al otro lado del acaso (2012). The later was published in Portuguese under the title Do outro lado do acaso (2018). Address correspondence to: José Cardona, e-mail: j.cardona72@yahoo.com.
} 